\title{
POLITICAL AND THEORETICAL APPROACHES TO THE ESSENCE AND TYPES OF ENTREPRENEURSHIP
}

The purpose of the study is to consider the process of development of society in the context of the dominant production relations, in the state of the economy and in its political orientation. It is noted that the political structure of society has always been subject to changes, not only in terms of changing ideas, but also in the policy regarding entrepreneurship and its position in the development of the national economy.

Research methods. In the process of studying the topic, such methods were used as the analysis of the theoretical foundations of the development of entrepreneurship as a socio-economic institution, the analysis of a special set of norms and rules that ensure the coordinated behavior of business entities.

The novelty of the study is that for the first time in a national economic study, a variety of concepts and approaches on the problems of the development of the institution of entrepreneurship were clearly classified. However, the growth of political entrepreneurship and international cooperation between entrepreneurs has caused a dramatic change in its essence, so a political analysis of the problem is key to understanding the role of the main subsystem of the modern free market economy.

Conclusions. Summing up, the author comes to the conclusion that, from the point of view, the thesis about two models of entrepreneurial behavior can help resolve the contradiction in the nature of innovation in entrepreneurship (classical and innovative). It is noted that the distinctive feature of the first model (otherwise it can also be called resource-oriented) is that the entrepreneur links tasks with available resources and prefers means of achieving goals that ensure the most efficient use of resources. The second model is focused on opportunities rather than resources, which means that the entrepreneur prefers innovative production methods using his own resources and external resources. In a word, modern entrepreneurship is a multidimensional and holistic socio-economic phenomenon of a market economy, in which multilevel (reflecting many theoretical concepts) and generalizing (reflecting many features) approaches are extremely important. It is advisable to define its economic essence.

Key words: entrepreneurship, market economy, political entrepreneur, economic structure, political theory. JEL Classification: L26, D40, H10.

\section{Sakina BABAYEVA,}

Ph.D. Student

Western Caspian University

orcid.org/0000-0001-5211-8359

\section{Introduction (relevance)}

The modern stage of economic development has made it necessary to systematize the political and economic knowledge of entrepreneurship, and entrepreneurial activity in itself creates a basis for qualitative changes in the economic relations of the modern system of ownership.

The very importance of the theoretical systematization of any socio-economic and political-economic event is to understand its essence. In this regard, it is important to note that numerous approaches to the definition of entrepreneurship and the application of this concept in many contexts, including economic development, competition, valuation, profit, firm, production factors, and so on, do not allow to form of a unified and unambiguous definition of the term. One argues that "economic theory can hardly figure out a clear and general interpretation of this phenomenon" (Moskovtsev, Yurova, 2008: 91). There is a need for such an interpretation of entrepreneurship both in economic and political science, and in our point of view, the issue can be defined if it is grounded on the definition of entrepreneurship with emphasizing its specific features using four basic approaches:

1) a broad and narrow approach;

2) macro and microeconomic approach; 
3) an approach based on the characteristics of research programs;

4) political and theoretical approaches

In brief, entrepreneurship is characterized as a private type of economic activity. The main feature here is that the activity is based on an independent initiative, responsibility, idea of innovation and aims to make a profit.

\section{Goal research}

The purpose of the study in this article is to consider the process of development of society in the context of the dominant production relations, in the state of the economy and in its political orientation. It is noted that the political structure of society has always been subject to changes, not only in terms of changing ideas, but also in the policy regarding entrepreneurship and its position in the development of the national economy.

\section{Research methods}

In the process of studying the topic, such methods were used as the analysis of the theoretical foundations of the development of entrepreneurship as a socio-economic institution, the analysis of a special set of norms and rules that ensure the coordinated behavior of business entities.

\section{Research novelty}

The novelty of the study is that for the first time in a national economic study, a variety of concepts and approaches on the problems of the development of the institution of entrepreneurship were clearly classified.

\section{Review of recent publications}

In his research, the author analyzed the works of 16 researchers who, to one degree or another, put forward their ideas and approaches to the development of an entrepreneurial institution. Works of such authors as A.F. Moskovtsev, O.V. Yurova "The heuristic meaning of the concept of entrepreneurship and its boundaries" (Moskovtsev, Yurova, 2008); N. Cohen "Policy Entrepreneurs and the design of the public policy: Conceptual Framework and the case of the National Health Insurance Law in Israel" (Cohen, 2011); M. Mintrom and P. Norman "Policy Entrepreneurship and Policy Change" (Mintrom, Norman, 2009); J. Huerta de Soto "Socialism, economic calculation and the entrepreneurial function" (Huerta de Soto, 2008); M. Emirbayer and A. Mische "What is agency?" (Emirbayer, Mische, 1998); K. Buhr "The inclusion of aviation in the EU Emissions Trading Scheme: Temporal Conditions for the Institutional Entrepreneurship, Department for Transport" (Buhr, 2012); N.P. Kononkova "The public sector of the Russian economy: entrepreneurship opportunities" (Kononkova, 2010); N.I. Kraskova "Small business as a subject of analysis of economic science" (Kraskova, 2011); L.V. Grishaeva and G.T. Kuzhbanova "To questions about the essence of entrepreneurship" (Grishaeva, Kuzhbanova, 2012).

\section{Main material views}

According to the macroeconomic approach, entrepreneurship is defined as a subsystem within the complete structure of the economy. Economic activity can also be regarded as a system of activity which requires to achieve the goals for the recovery of an economic entity and to get profits under resource constraints. So, entrepreneurship contributes to the activity of a complete economy and in this regard acts as an economic status in public policy. This type of subsystem can manifest itself in the activities of both local and other economic entities, regional or territorial economic unit, national economic entity, and even has the right to exist in the business entity at the national level.

Entrepreneurship policy is institutionalized as a subsystem in the general structure of the economy of each state with its own developmental tendency to fulfil socially important economic functions.

From the standpoint of the microeconomic approach, the essence of entrepreneurship policy is defined as a specific type of business behaviour of a person, an individual, a private enterprise or a company. The main point of the entrepreneurial activity is manifested in specific goals, characteristics, and motivations (for instance, individual or self-realization).

Some representatives of the neoclassical school of political and economic thought have interpreted entrepreneurship as a unique and uncommon production factor. In this regard, the following definition is used in this course: entrepreneurial activity is a process of earning commercial income by realization of an individual's abilities expressed in an efficient combination of production factors based on risk-taking. According to V.M. Niftullayev's research, "Entrepreneurship is the type of activity carried out by individuals, enterprises and organizations in the production, service, sale and exchange of other products. 
1. Subjects of entrepreneurship may be individual persons, enterprises and their associations.

2. Creating certain economic, social and legal conditions for the establishment of entrepreneurial activity is necessary.

3. Different by types and forms of entrepreneurship, such as production, trade, mediation, consultancy, finance and others. The abovementioned types of entrepreneurship can operate in groups, individually, and also a whole unit. For example, business activities, production and trade, and so on. Depending on the form of property, the property may be private, state, municipal, and public property.

4. The following organizational and legal forms of entrepreneurial activity have been developed in modern times: economic partnerships and societies; production cooperatives; state and municipal unitary enterprises. Economic partnerships can be created in the form of limited liability, extra liability companies, as well as joint-stock companies and associated companies" (Niftullayev, 2002: 32).

The political innovation concept of entrepreneurship defines it as a specific type of activity which is distinct from traditional labour activity in terms of innovation method, scope and criteria.

The institutional concept of entrepreneurship describes it as a socio-economic institution, that is, a specific set of norms and rules that ensure the coordinated behaviour of economic entities. The norms that form the institution of entrepreneurship are based on traditions, diligence, thriftiness, business ethics, as well as labour rights, agreements, legislation and other norms form the institution of entrepreneurship creates formal regulators in the form of organizational standards.

We particularly emphasize the interpretation of entrepreneurship proposed by the former Soviet School of Economics, as it does not conform to any of these concepts, and its representatives use a level approach: the level of essence and form. In the political definition of entrepreneurship, it is interpreted as an economic category of a market economy. The shortest and most comprehensive definition of the market economy is simple as following: "the economy of free enterprises". In this regard, entrepreneurship policy is a complete set of economic relations related to the implementation of entrepreneurial activity and profit. These relations comprise connections with other economic entities (State and households), as well as mutual relations between entrepreneurs. In the political form, entrepreneurship is also considered as an economic method and process.

Entrepreneurial policy is also characterized by the following features:

- freedom and independence of economic entities;

- economic risk and responsibility;

- economic interests of economic units;

- innovation.

Entrepreneurship policy as a process is a sequence of determined actions of entrepreneurs from the first time of creation of the idea of entrepreneurship until its inclusion in a specific entrepreneurship project.

Interestingly enough, the former Soviet economic school emphasizes that the economic category of entrepreneurial policy has a historical character, which means the concept is not something definitively formed. The evolution of entrepreneurial terminology, content, and actions reflects the history of the exchange, production and distribution of goods and services, and at the same time the level of development of scientific and technical progress in this context. Therefore, at different stages of the development of societies ideas about entrepreneurship and its position in the development of the national economy are influenced and changed according to the dominant industrial relationships, the condition of the economy, the political structure.

Besides, because of the variety of tasks that may be required from entrepreneurs, as well as the diversity of objective external conditions, formal definition of entrepreneurship will always be varying correspondingly to the existing conditions.

In entrepreneurship policy, to resolve some issues formal and serious decisions need to be made, for the solution of the other problems, a more generally agreed approach is required to understand the essence behind one or another approach.

Modern entrepreneurship policy is characterized by several manifestations, such as business conditions and economic activity parameters. Particularly, in economic aspect, entrepreneurship can be observed as a production factor, economic relations, economic method, and even an economic institution. Each of these components has respectable quality features. This means that none of these definitions can be considered complete independently. However, at the same time, these components are characterized by general, specific features that help determine their essence. 
But what is the explanation of the term "political entrepreneur"? It is well known that a political entrepreneur is an individual who uses the state's political decisions and opportunities regarding entrepreneurship to achieve personal goals that an individual cannot achieve by moving outside the political context. According to American political scientist J.W. Kingdon, "The term of political entrepreneur does not depend on a specific occupation of a particular individual: a political entrepreneur may or may not be an official in the government, can be a CEC employee, or even maybe in a leading position in a group or be a member of a research organization, whether he or she is designated or elected" (Kingdon, 1984). In this sense, the key feature of a political entrepreneur is that they want to invest in resources, time, energy, authority or money, in order to make any political change to achieve profit in the future. From this point of view, a political entrepreneur is very similar to a classic businessman, and the core difference is only in their field of activity.

Quite a few researchers, including D.D. Li, F. Junxin and J. Hongping note that there is a fundamental difference between an ordinary entrepreneur and "political" entrepreneur: "This is because the changes that political entrepreneurs make are not only attributable to them but also contribute to other agents operating within the framework of the changed structures of political entrepreneurs" (Li et al., 2006). Thus, it is important to differentiate between the concepts of "political entrepreneur" and "lobbying".

According to S. Ainsworth and I. Sened, "Lobbyists are, first of all, a kind of link between the interest groups (which is leader is a political entrepreneur) and the authorities. Some scholars consider lobbyists to be a subset of political entrepreneurs" (Ainsworth, Sened, 1993).

N. Cohen writes: "The term of "political entrepreneurship" and concepts relating to political entrepreneurship emerged in the early 1980s as a part of scientific researches on political science and management" (Cohen, 2011) In addition to "political entrepreneurship", other types of this concept including "institutional entrepreneurship", "executive entrepreneurship", "evolutionary political activity" and others also formed. The main reason for the research is the need for a new approach to the phenomenon of political change. According to M. Mintrom and P. Norman, "Theories of political change was the first emerged hypotheses (in the late "60s)" (Mintrom, Norman, 2009). That means the concepts of "political entrepreneurship" and "political entrepreneurs" were developed later.

The window of opportunity - is the concept used to describe the moment which is the most optimal time for the political entrepreneur to make the necessary changes. In the context of political entrepreneurship, the concept was first used by J.W. Kingdon in his book "Agendas, Alternatives and Public" (Kingdon, 1984).

J.W. Kingdon's theory of illustration implies that three so-called "streams" must be brought together to successfully address the activities of political entrepreneurs. The meaning of the first "flow" is that the need for any change (such as reform) should be understood by society (primarily the political elite) as a problem (Problem Stream). The second "flow" is the desire and will to develop a policy mechanism (Policy Stream) that has been developed to address the problem, and the third is the desire and will to make the necessary changes (Politics Stream) within authorized political institutions. As J.W. Kingdon notes: "When all "three streams" converge, political entrepreneurs should only expect for a favourable political situation - "a window of opportunity"” (Kingdon, 1984).

We broadly interpret the definition of entrepreneurship as a process of human activity: "Broad or general entrepreneurship is the same as human activities. In this regard, that can be said, almost anyone willing to change their present-day and also achieve their future goals will be engaged in entrepreneurship activity" (Huerta de Soto, 2008: 47).

Criticism of political entrepreneurship is primarily based on the notion of "integrated agent". According to this concept, R. Garud, C. Hardy and S. Maguire note: "An individual within certain political organizations and institutions cannot anticipate or make any changes in the activities of these institutions or other institutions. The motive of the issue is the phenomenon of "integrated agent", so: the institutions structures individual's consciousness, recognizes interests and identities, makes it impossible for an individual to go beyond the institutional framework and hence carry out any reforms" (Garud et al., 2007). The response to this criticism shows that the environment in which many researchers, agents (including political entrepreneurs) operate is created by agents themselves and that the process is temporary. From this aspect, according to M. Emmirbayer and A. Mischey: "Agents at any time can rebuild it or, in principle, create something new, because the sole purpose of their environment, which created by themselves, is to institutionally respond to the constantly changing conditions of the world in any historical development stages" (Emirbayer, Mische, 1998). So, institutional entrepreneurship is necessary at any moment. 
One of the most noticeable examples of the activities of political entrepreneurs was the including of the aviation sector into the European Union system for greenhouse gas emissions trading. As K. Buhr points out: "This system was put into operation in 2005 and its main goal was to reduce greenhouse gas emissions from the EU countries to meet the environmental standards that were set out in the Kyoto Protocol, which came into force in 2005. The emission trading system is divided into three provisional phases, and the first phase, which began in 2005, included only the areas of the highest energy consumption and the emissions generated by generators themselves" (Buhr, 2012).

Many have been left astounded by the fact that the aviation sector has already passed the first phase. Accordingly, long before the first phase came into effect in 2005, a circle of political entrepreneurs was established. This circle included several European Commissioners, direct representatives of the aviation sector, as well as several NGOs such as the European Federation for Transport and Environment. Soon later, several scientific centres and research organizations joined to the establishment (Kononkova, 2010: 14).

As a result of the collective efforts, the impact of aviation emissions on the environment were known and thoroughly investigated. The necessity to limit aviation emissions has become clear to the general public (Problem Stream). Political entrepreneurs have conducted comparative analysis of various mechanisms for reducing emissions (for example, comparing the efficiency of emissions trading with direct taxation of emissions) and concluding that emissions trading mechanisms are the most cost-effective and agile (especially for the aviation industry). Thus, the appropriate policy (Policy Stream) developed. The political "flow" has been around since the beginning, as some of the political businessmen were members of the European Commission.

As the United Kingdom started to expand its fleet from 2003 there was an urgent need to adopt some mechanism to regulate aviation emissions and in 2005 when the UK chaired the EU Council "The Opportunity Window" opened.

Principally, specific features of entrepreneurship include initiation, independence, responsibility, economic uncertainty and a high level of economic risk and profitability (Timofeev, 2010: 45). In this sense, V.F. Bogachev, V.S. Kabakov and A.M. Khodachek believe that Entrepreneurship diverges substantially from commercial activities in budgetary organizations with strict tasks, regulations, reporting and under the control of the owner (Bogachev et al., 1995: 72).

It is worth to mention that there is still no consensus on the distinctive marks of entrepreneurial activity such as innovation, nor about the right to ownership of production factors. In this regard, four main approaches can be identified.

N.I. Kraskova writes: "According to the first approach (J. B. Sey, Austrian School, the Soviet School of Economics), the innovative nature of entrepreneurial property rights and means of production is a characteristic of entrepreneurial activity. Representatives of the Soviet School of Economics are exploring the formation and development of the concept of "entrepreneurship", which is closely linked to the concept of property, and in this regard, entrepreneurship and property are viewed as two sides of the same process that evolves over time and space" (Kraskova, 2011: 44).

The second approach to entrepreneurial activity is that ownership of production means is more necessary rather than the innovative nature of the activity. A number of scholars and economists, for example, A. Smith, J. Bodo, I. V. Lipsitz, A. Busygin assert such ideas.

Proponents of the third approach (like R. Catilon) accept as true that an entrepreneur can own a business, can only be a manager, and the innovative nature of the activity is not imperative. This is the largest approach in the matter of the scope of economic units.

Adherents of the fourth approach (Y. Schumpeter, P. Druker, V. Kushlin) think that innovation is the core principle of entrepreneurship, and possession of an enterprise is not an essential attribute of entrepreneurship, as entrepreneurship is possible even when there is no personal equity (eg, obtaining a business loan, using funds or through government grants).

In practice, the second approach has been supported, and also evidenced by the definition of entrepreneurship in the civil code of the Russian Federation defined as mentioned above.

\section{Conclusions}

In our point of view, the thesis about two models of entrepreneurial behaviour can be helpful to resolve the contradiction about the nature of innovation in entrepreneurship: the classical and the innovative. The distinctive feature of the first model (otherwise it can also be called a resource-oriented model) is that the entrepreneur aligns the tasks with the available resources and prefers the means to achieve the goals that ensure the most efficient use of resources. The second model is focused on opportunities, not resources, 
which means that the entrepreneur prefers innovative methods of production using his resources and external resources.

L.V. Grishaeva avd G.T. Kuzhbanova shows that entrepreneurship can be defined according to the following basic theoretical approaches:

1) as an economic category of a market economy;

2) as an economic method and process;

3) as a special production factor;

4) as an institution (Grishaeva, Kuzhbanova, 2012: 48).

So, modern entrepreneurship is a multi-dimensional and integral socio-economic phenomenon of a market economy, in which, from our point of view, a multilevel (reflecting a variety of theoretical concepts) and generalizing (reflecting many specific features) approaches is exceedingly appropriate to determine its economic essence.

\section{References:}

1. Moskovtsev, A.F., Yurova, O.V. (2008). Evristicheskoye znacheniye ponyatiya predprinimatel'stva i yego granitsy [Heuristic meaning of the concept of entrepreneurship and its boundaries]. Ekonomicheskie nauki - Economic Science, no. 7, pp. 91-94 [in Russian].

2. Niftullayev, V.M. (2002). Sahibkarlı̆ğın əsasları [Basics of entrepreneurship]. Baku: Zaman nəşriyyatı [in Azeri].

3. Kingdon, J.W. (1984). Agendas, Alternatives, and Public Policies. 2nd ed. Boston: Little, Brown and Company [in English].

4. Li, D.D., Junxin, F., Hongping, J. (2006). Institutional Entrepreneurs. American Economic Review, vol. 96, no. 2, pp. 358-362 [in English].

5. Ainsworth, S., Sened, I. (1993). The Role of Lobbyists: Entrepreneurs with Two Audiences. American Journal of Political Science, vol. 37, no. 3, pp. 834-866 [in English].

6. Cohen, N. (2011). Policy Entrepreneurs and the design of the public policy: Conceptual Framework and the case of the National Health Insurance Law in Israel. Retrieved from: https://www.openu.ac.il/lists/ mediaserver_documents/policy/maamar-7.pdf [in English].

7. Mintrom, M., Norman, P. (2009). Policy Entrepreneurship and Policy Change. Policies Studies Journal, vol. 37, no. 4, pp. 649-667 [in English].

8. Huerta de Soto, J. (2008). Sotsializm, ekonomicheskiy raschet i predprinimatel'skaya funktsiya [Socialism, economic calculation and entrepreneurial function] / transl. from English V. Koshkin; ed. by A. Kuryaev. Moscow; Chelyabinsk: IRISEN [in Russian].

9. Garud, R., Hardy C., Maguire, S. (2007). Institutional Entrepreneurship as embedded agency: an introduction to the special issue. Organization Studies, vol. 28, iss. 7, pp. 957-969 [in English].

10. Emirbayer, M., Mische, A. (1998). What is agency? American Journal of Sociology, vol. 103, no. 4, pp. 962-1023 [in English].

11. Buhr, K. (2012). The inclusion of aviation in the EU Emissions Trading Scheme: Temporal Conditions for the Institutional Entrepreneurship. Organization Studies, vol. 33, iss. 11, pp. 1565-1587 [in English].

12. Kononkova, N.P. (2010). Gosudarstvennyy sektor rossiyskoy ekonomiki: vozmozhnosti predprinimatel'stva [State sector of the Russian economy: opportunities for entrepreneurship]. Ekonomicheskie nauki - Economic Science, no. 6, pp. 13-16 [in Russian].

13. Timofeev, A.V. (2010). Predprinimatel'stvo - dvizhushchaya sila kachestvennykh sdvigov v epokhi peremen [Entrepreneurship is the driving force of qualitative changes in the era of change]. Ekonomicheskie nauki - Economic Science, no. 10, pp. 43-46 [in Russian].

14. Bogachev, V.F., Kabakov, V.S., Khodachek, A.M. (1995). Strategiya malogo predprinimatel'stva [Strategy of small business]. Saint Petersburg [in Russian].

15. Kraskova, N.I. (2011). Maloe predprinimatel'stvo kak predmet analiza ekonomicheskoy nauki [Small business as a subject of analysis of economic science]. Ekonomicheskie nauki - Economic Science, no. 1, pp. 43-46 [in Russian].

16. Grishaeva, L.V., Kuzhbanova, G.T. (2012). K voprosu o sushchnosti predprinimatel'stva [To questions about the essence of entrepreneurship]. Voprosy ekonomiki i prava - Questions of Economics and Law, no. 3, pp. 45-48 [in Russian]. 


\title{
ПОЛІТИЧНИЙ І ТЕОРЕТИЧНИЙ ПІДХОДИ ДО СУТНОСТІ ТА ВИДІВ ПІДПРИЄМНИЦТВА
}

\author{
Сакіна БАБАСВА, \\ докторант \\ Західно-Каспійського університету \\ orcid.org/0000-0001-5211-8359
}

Мета дослідження - розглянути процес розвитку суспільства в контексті домінуючих виробничих відносин, у стані економіки та в їі політичній спрямованості. Зазначається, що політична структура суспільства завжди зазнавала змін не лише у плані ідей, а й у політиці щодо підприємництвва та його позицї̈ в розвитку начіональної економіки.

Методи дослідження. У процесі вивчення теми були використані такі методи: аналіз теоретичних основ розвитку підприємниитва як соціально-економічного інституту, аналіз особливого набору норм і правил, щя забезпечують узгоджену поведінку господарюючих суб'єктів.

Новизною дослідження $є$ те, що в наиіональній економічній науці вперше було чітко класифіковано безліч конщепиій і підходів до проблем розвитку інституту підприємництва.

Однак зростання політичного підприємництва та міжнародного співробітництва між підприємиями зумовлює різку зміну його суті, тому політичний аналіз проблеми є ключовим для розуміння ролі основної підсистеми сучасної економіки вільного ринку.

Висновки. Підводячи підсумки, автор доходить висновку, що теза про дві моделі підприємницької поведінки може допомогти вирішити протиріччя у природі інновацій у підприємництві (класичної та інноващійної). Зазначається, щуо відмінна риса першої моделі (ї̈ ще можна назвати ресурсно-орієнтованою) полягає в тому, що підприємець пов'язує завдання з наявними ресурсами та обирає засоби досягнення цілей, які забезпечують найбільш ефективне використання ресурсів. Друга модель орієнтована на можливості, а не на ресурси, що означає, що підприємець обирає інноваційні методи виробництва з використанням своїх ресурсів і зовнішніх ресурсів. Словом, сучасне підприємництво - це багатовимірне й иілісне соціальноекономічне явище ринкової економіки, у якому надзвичайно важливі багаторівневий (що відображає безліч теоретичних конщепщій) та узагальнюючий (що відображає багато особливостей) підходи. Доиільно визначити його економічну сутність.

Ключові слова: підприємництво, ринкова економіка, політичний підприємець, структура економіки, політична теорія. 